\title{
Effects of Sulfur and Manganese Micronutrients on the Yield of Soybean Varieties
}

\author{
Atabayeva Khalima Nazarovna, Namozov Fazliddin Bakhromovich, \\ Kurbonov Akhmad Alavkhonovich, Kayrullayev Sardor Shamsiddin Ugli \\ Department of Soybean and Oilseed Crops, Tashkent State Agrarian University, Tashkent, Uzbekistan \\ Email: sardorxayrullayev@mail.ru
}

How to cite this paper: Nazarovna, A.K., Bakhromovich, N.F., Alavkhonovich, K.A. and Ugli, K.S.S. (2020) Effects of Sulfur and Manganese Micronutrients on the Yield of Soybean Varieties. Agricultural Sciences, 11, 1048-1059.

https://doi.org/10.4236/as.2020.1111068

Received: August 4, 2020

Accepted: November 13, 2020

Published: November 16, 2020

Copyright $\odot 2020$ by author(s) and Scientific Research Publishing Inc. This work is licensed under the Creative Commons Attribution International License (CC BY 4.0).

http://creativecommons.org/licenses/by/4.0/

\begin{abstract}
In this article, it is given about lengthening of praxis period, stem and leaf growth, leaf surface, number of stems and weight than the control variant soybean varieties, and the yield and grain quality of soybean varieties are significantly higher when the three types of sulfur and manganese on background of mineral fertilizers are applied in suspension in the condition of meadow-swamp soil. In the soybean varieties, mineral fertilizers were used in the variant with an additional yield of around $5-12 \mathrm{c} / \mathrm{ha}$ compared to the control. According to the norms of the manganese element, around $7-20$ c/ha; when using sulfur, the yield in soybean varieties is around $8.0-18.0$ c/ha. On the background of mineral fertilizers, grain quality has changed due to micronutrients. Protein content in the "Orzu" variety increased by $3.1 \%$ $8.4 \%$ when manganese and sulfur elements were used; in the "Nafis" variety, the protein content was found to increase by $6.1 \%-8.5 \%$.
\end{abstract}

\section{Keywords}

Soybean, Mineral Fertilizer, Micronutrients, Manganese, Sulfur, Norm, Growth, Development, Tubers, A Piece of Soybean Grain, Leaf Weight, Leaf Surface, Yield

\section{Introduction}

Nowadays, when protein deficiency is prevalent all over the world, the protein richness of soybean grains, and the presence of all the amino acids in the protein content are particular importance, and useful for humans, and it is further increasing the nutritional value of soybeans. It should be noted that the advantage of soybean can be compared with a number of foods in terms of richness in lysine, methionine, arginine, leucine and other essential amino acids. In many 
countries where soybeans are grown, this crop is the only source of protein, which also provides livestock with nutritious food and increases its productivity. Soybean contains $28 \%$ - $52 \%$ protein, $18 \%$ - $27 \%$ ecologically pure vegetable oil, many mineral salts and nutrients, which can be compared with the most important food products such as meat, milk, eggs in terms of high quality amino acids.

Due to the positive biological properties of soybeans in the country, special attention is paid to the norms of sowing, norms of mineral fertilizers in the creation and improvement of technology for growing soybeans. Soybean cultivation requires scientific research on the efficient use of water and land resources to obtain additional crops, with a strong emphasis on micronutrients, stimulants, growth regulators. Soybeans contain $30 \%-52 \%$ protein, $17 \%-27 \%$ oil and $20 \%$ carbonated water. The high prevalence of soybean in the world is related to the quality of grain and protein. The amount and proportion of protein, oil and other important organic and mineral substances in the grain allow it to be used in various industries. Soybean grain is used to make butter, margarine, cheese, milk, flour, confectionery and canned food. Soybean oil amounts to $40 \%$ of the world's vegetable oil production [1].

In Uzbekistan, according to several government decisions, the area under soybeans is being expanded; yields are increasing; our national varieties are being created and foreign varieties are being introduced. Scientific and practical work on soybean varieties is being carried out in different soil and climatic conditions of Uzbekistan. Tashkent State Agrarian University is preparing special workforces in soybean cultivation.

\section{Literature Review}

Micronutrients optimize plant nutrition, increase resistance to stress, stimulate growth [2]. If manganese, barium and molybdenum are not enough, seeds will not form in the pods. At the beginning of the growing season, molybdenum and barium have a positive effect on the plant [3]. Such cases are also observed in the soybean plant [4]. According to the biological potential of modern soybean varieties, it is possible to grow $3.5-4.4 \mathrm{t} / \mathrm{ha}$ of seeds, but in practice this is very difficult to achieve [5]. In order to get a yield of $30 \mathrm{c} /$ per hectare, it is necessary to apply mineral fertilizers at the rate of $\mathrm{P}_{90} \mathrm{~K}_{60}$. The effectiveness of phosphorus and potassium fertilizers under irrigated conditions depends on the water supply, when applied in moderation, the yield is $34-36 \mathrm{c} /$ ha above the soybean. When legume crops are fed in symbiosis with nitrogen, the demand for phosphorous and potassium fertilizers increases significantly [5].

Micronutrients are relatively poorly received by the soybean plant as nitrogen, phosphorus, potassium, calcium, magnesium and manganese. Nevertheless, their importance is not small, the lack of micro elements in the soil slows down the growth rate of the plant, the yield is reduced. Deficiency of micronutrients increases the resistance of soybean plants to diseases. When fully supplied with micronutrients, the number of flowers and fruits in plants increases that, ensures 
full maturation, helps to transportation of nitrogen and photosynthesis products in the plant. Depending on the phosphorus supply of the soil, the following norms of phosphorus fertilizers were recommended. It was determined that when the soil content of phosphorus is very low $(1.5 \mathrm{mg} / 100 \mathrm{~g})$ it is necessary to apply $120 \mathrm{~kg}$ of pure substance per hectare, at least $90 \mathrm{~kg}$, on average $75 \mathrm{~kg}$ of phosphorus fertilizer [6].

Lack of potassium in the plant reduces productivity, reduces resistance to external conditions and disease. When potassium is sufficient, the plant becomes vigorous, grows and develops well, increases resistance to drought and disease, and is well preserved [7].

Air nitrogen assimilation takes place in the presence of micro elements in soybean plant, especially molybdenum and cobalt. In the process of nitrogen fixation, molybdenum improves plant nitrogen nutrition, increases the effectiveness of phosphorus and potassium fertilizers. As the yield increases, so does the protein content of the grain.

Soybean yield is not formed due to deficiency of micronutrients. Macro fertilizers must be used in soybean cultivation. The fertilization system plays an important role in increasing the yield of soybeans. The plant requires mineral nutrition: for the cultivation of $1 \mathrm{t}$ of seeds requires $70-90 \mathrm{~kg}$ of nitrogen, $15-20$ phosphorus, 30 - 40 potassium, 8 - 10 magnesium, $18-21 \mathrm{~kg}$ of calcium. The amount of nutrients falling on the plant during the application period is not the same. From mowing to flowering, the soybean absorbs $5.9 \%-6.8 \%$ of nitrogen, $4.6 \%-4.7 \%$ of phosphorus and $7.6 \%-9.4 \%$ of potassium relative to the total absorbed volume. The most nutritious period is flowering, legumes and grain filling. During these periods, nitrogen was $57.9 \%-59.7 \%$, phosphorus $59.4 \%$ $64.7 \%$, and potassium $66.0 \%-70.0 \%$; nitrogen from the period of grain filling to the ripening period $33.7 \%-36.3 \%$, phosphorus $30.6 \%-36.0 \%$ and potassium $18.9 \%-26.4 \%$. The upper part of nitrogen is assimilated during flowering and budding, the main part of phosphorus is absorbed from mowing and branching, the main part of potassium is assimilated during budding and grain filling. Mineral fertilizers play an important role in soybean cultivation technology [8]. When growing soybean without fertilizer, the yield was $16.9 \mathrm{c} /$ ha per hectare, the protein content was $35.7 \%$. When $\mathrm{N}_{60} \mathrm{P}_{60} \mathrm{~K}_{60}$ was applied per hectare, it was found that the grain yield was $21.9 \mathrm{c} /$ ha and the protein content was $39.3 \%$. It was noted that due to mineral fertilizers, the yield of soy increased by $1.2-4.9 \mathrm{c} / \mathrm{ha}$ [8] [9].

Effective methods of feeding soybean yield should be used. Iron is a component of chlorophyll and is important in respiration and photosynthesis. In iron deficiency, chlorophyll production stops abruptly. The interstices of young leaves turn yellow. As the deficit increases, the leaf veins also turn yellow and the leaf turns completely white. Brown spots appear on the edges of the leaves.

Iron deficiency is common in soils with a soil environment $\mathrm{pH}$ greater than 7. Soybean varieties have different approaches to iron deficiency. In resistant varieties, the assimilation of iron begins with the root system, and in a well-developed 
root system, iron is assimilated from various root wastes. As the $\mathrm{pH}$ of the soil increases, the absorption of manganese becomes more difficult.

According to the results of scientific studies, in order to provide the soil with phosphorus-potassium, phosphorus and potassium fertilizers are recommended from $20 \mathrm{~kg}$ to $120 \mathrm{~kg}$ per hectare before plowing in the fall [10] [11] (References are ordered corrected).

\section{Experimental Methods and Conditions}

The experiment was conducted on the experimental farm of the Uzbek Rice Research Institute in 2018-2019. The soil is swampy. The experimental field is located in the south-eastern part of the Tashkent region, $15 \mathrm{~km}$ from Tashkent, on the left bank of the Chirchik River on the Greenwich scale at $69^{\circ} 18^{\prime}$ east longitude and $41^{\circ} 20^{\prime}$ north latitude.

The soil of the experimental field is not saline, the driving layer is $30-40 \mathrm{~cm}$. The $\mathrm{pH}$ of the solutions in the soil is in the range of $6.8-7.3$ units and is heavy clay in mechanical composition. Rice was a predecessor to the soybean crop. Field experiments in 4 rounds, the piles were $10 \mathrm{~m}$ long and $2.4 \mathrm{~m}$ wide. There are 4 rows, the total area of each pile is $24.0 \mathrm{~m}^{2}$, of which 2 rows of main in the middle, 2 rows of protection rows on the edges. Variants are placed by randomization method.

"Data on the sum of useful air temperature, precipitation amount and relative humidity in the experimental conditions. The sum of air temperature, precipitation amount and relative humidity in 2018 and 2019 were determined over the months. The average daily temperature above 10 degrees was calculated. The climate of the Tashkent region is also sharply continental, with extremely hot summers and cold winters, as well as dry weather and natural rainfall, which is extremely low for plant growth. The soil layers are typical for the oasis and are swamp-type soils. There are also mixtures of large and small stones and sand in different depth layers. These soils are due to the typical excess moisture conditions on the left bank of the river and are very suitable for rice cultivation. Soil-meadow, the soil of the experimental field is not saline, the plowing layer is $30-40 \mathrm{~cm}$. The $\mathrm{pH}$ of the solutions in the soil is in the range of $6.8-7.3$ units and is heavy clay in mechanical composition. The experiments are conducted on the $2^{\text {nd }}$ edge of the $13^{\text {th }}$ card".

Conducting field calculations, calculations and observations were carried out on the basis of "Methodological manual of the State Commission for Variety Testing of Agricultural Crops (1989)", "Methods of field experiments (UZCSSRI, 2007)" and B. A. Dospekhov's "Methodology of field experiment". Leaf level was determined in the method of A. A. Nichiporovich by means of leaf cuttings, for which 5 typical plants were taken from the protective rows and analyzed. Leaf surface was determined during the application period, when 4 leaves appeared, in the flowering and budding phase. The number and weight of tubers in this period were determined by the method of G. S. Posypanov. To determine the 
weight of the roots, a monolith is dug in the size of $60 \times 5 \times 30 \mathrm{~cm}$, the roots are washed and weighted both wet and dry. Biometric measurements were performed on the counted plants prior to harvest. The plant height, number of leaves, leaf surface, weight of 1000 grains were determined. To determine the yield, the pods were collected, measured, crushed, and the grain was pulled from the accounted area of the stalks. Yield was determined by converting the yield per hectare, using the number of bushes per hectare. The amount of protein and oil in the grain was determined in special laboratories.

Methods and norm for the application of macro and micro fertilizers in the experiment: the experiment involved "Orzu" and "Nafis" varieties of soybeans, mineral fertilizer background-nitrogen 50 , phosphorus-100, potassium 75 $\mathrm{kg} / \mathrm{ha}$, manganese and sulfur standards 2.1 and $1.25 \mathrm{~kg} / \mathrm{ha} .2 .5,5.0$ and 7.5 grams of manganese and 1.5, 3.0 and 4.5 grams of sulfur were added to 10 liters of water, and this solution was applied by suspension in period of ovary and at the end of the flowering.

Definition of varieties: "Orzu" is an early maturing variety, it takes 35 - 40 days from planting to flowering, $110-120$ days before ripening, the stem is branched. The stem grows erect, the stem is hollow, the stem height is $50-70$ $\mathrm{cm}$. can be up to. The leaves are three-lobed, large, light green. The leaves of the plant are moderate, the leaves are symmetrical. The length of the leaf band is 10 $\mathrm{cm}$. When fully ripe, $75 \%$ of the leaves fall off. The flower is ok, there are $2-7$ flowers in the inflorescence. Pods are gray, small, $2.4 \mathrm{~cm}$ long. and $4.0 \mathrm{~cm}$. The pods do not crack when ripe, producing an average of about 40 pods per bush. The average grain size is 120 - 130 g per 1000 grains. Grain yield on irrigated lands is 32 centners per hectare. When sown as a secondary crop, $10-20 \mathrm{c}$ of grain is obtained. The grain contains $25 \%$ fat and $36 \%-38 \%$ protein. Authors: Rakhmanov AR, Yunusov BK, Tulaganov N., Bragina O.V.

The Nafis variety was created at the Uzbek Rice Research Institute by a single selection method.

Growth period is 115 - 125 days. Plant height $145-150 \mathrm{~cm}$. The location of the lower pods is $14-16 \mathrm{~cm}$, the number of branches is $2-4$, the number of pods per plant is $120-130$, the number of grains per pod is $2-4$.

Grain quality and technological parameters: weight of 1000 seeds $165-175 \mathrm{~g}$. Grain contains $40 \%-41 \%$ protein and $25 \%-27 \%$ fat. Designed to lie down, shed, be disease resistant and mechanized harvesting.

Yield: $30-32 \mathrm{c} / \mathrm{ha}$ of grain and $250-300 \mathrm{c} / \mathrm{ha}$ of blue mass can be obtained under favorable conditions".

\section{Results}

On the background of mineral fertilizers, micronutrients affected the growth, development, yield formation and grain quality of soybean varieties. Under the influence of micro elements, the praxis period of soybean varieties is extended. 
In the control variant and on the background of mineral fertilizers, the praxis period of "Orzu" variety was 107 - 106 days, under the influence of manganese standards it was 111 - 113 days. The validity period is extended to 4 - 6 days. Under the influence of the element sulfur, the praxis period was extended to 4 5 days (Table 1 ).

The "Nafis" variety lasted 124 - 130 days. It was found that the application period was extended by 2 - 6 days due to macro and micro fertilizers.

In the experiment, when the manganese was used in small amounts in the "Orzu" variety, the stem height was $116.4 \mathrm{~cm}$, which was $14.9 \mathrm{~cm}$ higher than the control variant; the stem height was $121.8 \mathrm{~cm}$ when the manganese medium was applied and $20.3 \mathrm{~cm}$ higher than the control, and $120.3 \mathrm{~cm}$ when used at the high standard, which was $18.8 \mathrm{~cm}$ higher than the control variant; when the sulfur microelement was used in small doses, the stem height was $112.4 \mathrm{~cm}$, which was $10.9 \mathrm{~cm}$ higher than the control variant. It was found that the height of the stem was $13.1 \mathrm{~cm}$ higher when the medium sulfur element was used and $16.6 \mathrm{~cm}$ when the high standard was used.

Table 1. Growth and development of soybean varieties under the influence of micro elements.

\begin{tabular}{|c|c|c|c|c|c|c|c|}
\hline No. & Variants & $\begin{array}{c}\text { Praxis } \\
\text { period, } \\
\text { a day }\end{array}$ & $\begin{array}{c}\text { Stem } \\
\text { height, } \\
\mathrm{cm}\end{array}$ & $\begin{array}{c}\text { Leaf } \\
\text { number, } \\
\text { pieces }\end{array}$ & $\begin{array}{c}\text { Leaf } \\
\text { surface, } \\
\text { thousand } \\
\mathrm{m}^{2} / \mathrm{ra}\end{array}$ & $\begin{array}{c}\text { Number } \\
\text { of } \\
\text { tubers, } \\
\text { pieces }\end{array}$ & $\begin{array}{c}\text { Weight } \\
\text { of } \\
\text { tubers, } \\
\text { gr }\end{array}$ \\
\hline \multicolumn{8}{|c|}{ Orzu variety } \\
\hline 1 & Control & 107 & 101.5 & 28.8 & 48.9 & 75.5 & 1.77 \\
\hline 2 & Background $-\mathrm{N}_{50} \mathrm{P}_{100} \mathrm{~K}_{70}$ & 106 & 107.5 & 30.0 & 50.1 & 89.5 & 1.88 \\
\hline 3 & Background + Mn-2.5 & 111 & 116.4 & 35.2 & 53.3 & 92.7 & 2.08 \\
\hline 4 & Background + Mn-5.0 & 113 & 121.8 & 37.2 & 55.9 & 95.4 & 2.10 \\
\hline 5 & Background + Mn-7.5 & 112 & 120.3 & 34.9 & 54.6 & 97.8 & 2.12 \\
\hline 6. & Background + S-1.5 & 110 & 112.4 & 34.5 & 52.0 & 93.6 & 2.11 \\
\hline 7 & Background + S-3.0 & 110 & 114.6 & 38.2 & 54.8 & 95.4 & 2.13 \\
\hline 8 & Background + S-4.5 & 111 & 118.1 & 37.9 & 54.2 & 95.3 & 2.14 \\
\hline \multicolumn{8}{|c|}{ Nafis variety } \\
\hline 1 & Control & 124 & 150.0 & 34.1 & 50.8 & 80.5 & 2.28 \\
\hline 2 & Background - $\mathrm{N}_{50} \mathrm{P}_{100} \mathrm{~K}_{70}$ & 126 & 156.8 & 38.7 & 52.6 & 83.7 & 2.35 \\
\hline 3 & Background $+M n-2.5$ & 130 & 162.3 & 39.8 & 55.6 & 82.7 & 2.38 \\
\hline 4 & Background + Mn-5.0 & 129 & 164.5 & 42.7 & 56.9 & 87.7 & 2.33 \\
\hline 5 & Background + Mn-7.5 & 127 & 163.3 & 41.1 & 55.9 & 85.5 & 2.36 \\
\hline 6 & Background + S-1.5 & 124 & 159.7 & 41.5 & 54.1 & 83.2 & 2.36 \\
\hline 7 & Background + S-3.0 & 128 & 163.6 & 43.3 & 55.9 & 89.5 & 2.35 \\
\hline 8 & Background + S-4.5 & 126 & 161.2 & 42.1 & 56.7 & 86.7 & 2.37 \\
\hline
\end{tabular}


In the control variant of the soybean variety "Nafis", the height of the stem was $150.0 \mathrm{~cm}$. In the variant where mineral fertilizers were applied, the stem height was $156.8 \mathrm{~cm}$, which was $6.8 \mathrm{~cm}$ higher than the control. In the experiment, it was observed that when manganese was used in small doses, the stem height was $162.3 \mathrm{~cm}$, which was $12.3 \mathrm{~cm}$ higher than the control variant; when manganese was used in moderation, the stem height was $164.5 \mathrm{~cm}$, which was $14.5 \mathrm{~cm}$ higher than the control, and when used in high norm, the stem height was $163.3 \mathrm{~cm}$, which was $16.3 \mathrm{~cm}$ higher than the control variant; when sulfur was used sparingly, the stem height was $159.7 \mathrm{~cm}$, which was $9.7 \mathrm{~cm}$ higher than the control. When the sulfur element was used in moderation, the stem height was $163.6 \mathrm{~cm}$, an increase of $13.6 \mathrm{~cm}$ compared to the control. When high levels of sulfur were used, the stem height decreased slightly to $161.2 \mathrm{~cm}$, which was $11.2 \mathrm{~cm}$ higher than the control.

During the legume period, 28.8 - 38.2 leaves developed in the control variant, and the number of leaves increased by $1.2-9.4$ in exchange for macronutrients. When the element manganese was used in small amounts, the number of leaves increased by 6.4 - 5.7 per variety; when manganese was used in middle norm, the number of leaves increased by 8.4 - 8.6 compared to control, and when used in high mode, the number of leaves increased by $6.1-7.0$; the number of leaves increased by $5.7-7.4$ compared to the control in varieties when sulfur was used sparingly; It was found that the number of leaves increased by 9.4 units in the "Orzu" variety and 7.4 units in the "Nafis" variety when sulfur was used in secondary norm, and the number of leaves increased by $9.1-8.0$ units in varieties when sulfur was used in secondary norm.

The formation and development of the leaf surface depends on the conditions of growth and development of the plant and the applied agronomic measures. The leaf surface of soybean varieties varied considerably in variants in exchange for the minerals and micronutrients used. During the legume period, the leaf surface of the varieties in the control variant was $48.9-50.8$ thousand $\mathrm{m}^{2} / \mathrm{ha}$ in the control variant; leaf area increased by $1.2-1.8$ thousand $\mathrm{m}^{2} / \mathrm{ha}$ in exchange for macro fertilizer.

When the manganese element is used in small amounts, the leaf surface increases by $4.4-4.8$ thousand $\mathrm{m}^{2} /$ ha by varieties; when manganese was used in secondary norm, the leaf area increased by $7.0-6.1$ thousand $\mathrm{m}^{2} /$ ha compared to the control, and when manganese was used in high standard, the leaf surface increased by $5.7-5.1$ thousand $\mathrm{m}^{2} / \mathrm{ha}$; when the sulfur element is used in small amounts, the leaf surface is $3.1-3.3$ thousand $\mathrm{m}^{2} /$ ha higher by varieties than the control variant; 5.9 - 5.1 thousand $\mathrm{m}^{2} /$ ha was observed with moderate use of sulfur and $5.3-5.9$ thousand $\mathrm{m}^{2} /$ ha with high use.

In soybean varieties, due to the presence of rhizobium bacteria in the experimental field, the tubers develop, in the control variant in soybean varieties developed 75.5 - 80.5 units. When applying mineral fertilizers, the number of tubers increased by 14.0 - 3.2 pieces by variety. When the element manganese was 
used in different amounts, it was observed that the number of tubers in the "Orzu" variety increased by 17.2 - 22.3, and in the "Nafis" variety by $2.2-7.2$. It was found that the number of tubers increased when the sulfur element was used small amount by 18.1 - 2.7 units compared to the varietal control, by $19.9-9.0$ units when used in secondary norm and by 19.8 - 6.2 units when applied in high amount. When the tubers are large, the symbiosis goes well and this helps to increase the nitrogen and organic matter in the soil. In the control variant by variety in the legume phase, the tubers weight was $1.77-2.28$ grams, which was $0.11-0.07$ grams higher than in the background of mineral fertilizers. It was found that due to micronutrients, the weight of the tubers increased by $0.1-0.35$ grams when the manganese element was used, and by $0.09-0.37$ grams when the sulfur element was used (Table 1).

The studied mineral fertilizers as a background and the norms of manganese and sulfur elements from micronutrients affected the yield of soybean varieties. The yield of the "Orzu" variety from the data of 2018 in the control variant was $18.8 \mathrm{c} /$ ha over the years. The variant of application of mineral fertilizers increased the yield by $6.2 \mathrm{c} / \mathrm{ha}$. When the manganese element was added to the background variant in small amounts, the grain yield was $33.0 \mathrm{c} /$ ha. The yield was $14.2 \mathrm{c} /$ ha higher than the control and $8.0 \mathrm{c} /$ ha higher than the background variant. When manganese was used in middle norm, the grain yield was 38.0 $\mathrm{c} /$ ha, which is $19.2 \mathrm{c} /$ ha higher than the control variant and $13.0 \mathrm{c} /$ ha higher than the background variant, and when manganese was used in high doses, the grain yield was $36.0 \mathrm{c} / \mathrm{ha}$, and it was compared to control and background variant. It was found to be $17.2 \mathrm{c} /$ ha higher than control and $11.0 \mathrm{c} /$ ha higher than background variant.

When the sulfur element was used in small quantities, an additional high yield of $11.2 \mathrm{c} /$ ha was obtained compared to the control variant. Compared to the background variant, the yield increased by $5.0 \mathrm{c} /$ ha. When the sulfur element was used in secondary quantities, it was found that $18.5 \mathrm{c} /$ ha more than the control variant, $12.3 \mathrm{c} /$ ha more than the background variant. And When the sulfur element was high quantities, it was obtained $17.6 \mathrm{c} /$ ha more than the control variant and $11.4 \mathrm{c} /$ ha more than the background variant.

The yield of the "Nafis" variety in 2018 was $22.6 \mathrm{c} /$ ha in the control variant. Yield increased by $11.8 \mathrm{c} /$ ha with the use of mineral fertilizers, $37.5 \mathrm{c} /$ ha was obtained with low manganese application in the background variant, which was $14.9 \mathrm{c} /$ ha in comparison with the control, and $3.1 \mathrm{c} /$ ha in comparison with the background variant. When manganese is used in mid-norm, the grain yield is $41.3 \mathrm{c} / \mathrm{ha}$, which is $18.7 \mathrm{c} / \mathrm{ha}$ more than the control variant and $6.9 \mathrm{c} / \mathrm{ha}$ more than the background variant, and when manganese is used in upper norm, it is $15.4 \mathrm{c} /$ ha more than the control variant and $3.6 \mathrm{c} /$ ha more than the background variant. When the element of sulfur was used in small amounts, $36.6 \mathrm{c} /$ ha was obtained, which is $14.0 \mathrm{c} / \mathrm{ha}$ higher than the control variant, and $2.2 \mathrm{c} /$ ha more than the background variant. The sulfur element yielded $39.4 \mathrm{c} /$ ha, when used in 
mid-norm, which was $16.8 \mathrm{c} /$ ha more than the control variant and $5.0 \mathrm{c} /$ ha more than the background variant. It was found that $38.6 \mathrm{c} / \mathrm{ha}$ was obtained when the sulfur element was used at a high rate, which was $16.0 \mathrm{c} /$ ha higher than the control variant and $4.2 \mathrm{c} /$ ha higher than the background variant.

According to the results of the experiment in 2019, the yield of the "Orzu" variety in the control variant was $19.1 \mathrm{c} / \mathrm{ha}$. In the variant where mineral fertilizers were applied, the yield increased by $5.5 \mathrm{c} / \mathrm{ha}$, when manganese element was added to the background variant in small amounts, the grain yield was $7.7 \mathrm{c} / \mathrm{ha}$ compared to the control and $2.2 \mathrm{c} /$ ha compared to the background variant. When manganese was used in mid-norm, the grain yield was found to be 10.1 $\mathrm{c} /$ ha higher than the control variant and $4.6 \mathrm{c} / \mathrm{ha}$ higher than the background variant. It was found that the manganese element yielded $27.6 \mathrm{c} /$ ha when applied at high altitude, which was $8.5 \mathrm{c} / \mathrm{ha}$ higher than the control and $3.0 \mathrm{c} /$ ha higher than the background variant. When the element sulfur was used in small amounts, it yielded $27.0 \mathrm{c} / \mathrm{ha}$, an additional $7.9 \mathrm{c} / \mathrm{h}$ compared to the control variant. It was observed that the yield increased by $2.4 \mathrm{c} / \mathrm{ha}$ compared to the background variant. When sulfur was used in secondary norm, an additional yield of $11.9 \mathrm{c} / \mathrm{ha}$ was obtained compared to the control variant, and $5.4 \mathrm{c} / \mathrm{ha}$ higher than that obtained in the background variant. When high levels of sulfur were used, the yield was $28.0 \mathrm{c} / \mathrm{ha}$, which was $8.9 \mathrm{c} /$ ha higher than the control variant and $3.4 \mathrm{c} /$ ha higher than the background variant.

The yield of the "Nafis" variety was $21.1 \mathrm{c} / \mathrm{ha}$ in the control variant. In the variant where mineral fertilizers were applied, the yield increased by $5.3 \mathrm{c} / \mathrm{ha}$, when manganese was used in small amounts in the background variant, it was $8.4 \mathrm{c} / \mathrm{ha}$ higher than in the control, and $3.1 \mathrm{c} /$ ha higher than in the background variant. When the manganese element was added to the background variant in the medium, the grain yield was $10.6 \mathrm{c} /$ ha higher than the control and $5.3 \mathrm{c} /$ ha higher than the background variant. When manganese was used in high doses, the grain yield was found to be $9.3 \mathrm{c} /$ ha higher than the control variant and $4.0 \mathrm{c} /$ ha higher than the background variant. The sulfur element yielded $29.8 \mathrm{c} /$ ha when used in small amounts, which was $8.7 \mathrm{c} / \mathrm{ha}$ more than the control variant and $3.4 \mathrm{c} / \mathrm{ha}$ more than the background variant. It was found that when the sulfur element was used in mid-norm, the yield was $10.6 \mathrm{c} /$ ha higher than the control variant and $5.3 \mathrm{c} /$ ha higher than the background variant (Table 2).

The studied micronutrients in the experiment affected the grain quality of soybean varieties on the background of mineral fertilizers. In the control variant, the protein content was almost the same by varieties, i.e. the protein content was 38.8 - 38.6. In the background variant, these figures were $40.4 \%-41.4 \%$, which was $1.6 \%-2.8 \%$ higher than in the control variant. When manganese was added in small amounts, the protein content was found to increase by $3.1 \%-6.2 \%$ compared to the control variant by varieties. When manganese was used in mid-norm, the protein content was found to be $43.0 \%-46.1 \%$ by varieties, an increase of $4.2 \%-7.5 \%$ compared to the control variant and $2.6 \%-4.7 \%$ 
Table 2. Yield of soybean varieties, $\mathrm{c} / \mathrm{ha}$.

\begin{tabular}{lccccc}
\hline & & \multicolumn{4}{c}{ Varieties } \\
\cline { 3 - 6 } No. & Variants & \multicolumn{3}{c}{ Orzu } & \multicolumn{3}{c}{ Nafis } \\
\cline { 3 - 6 } & & $\mathbf{2 0 1 8}$ & $\mathbf{2 0 1 9}$ & $\mathbf{2 0 1 8}$ & $\mathbf{2 0 1 9}$ \\
\hline 1 & Control & 18.8 & 19.1 & 22.6 & 21.1 \\
2 & Background $-\mathrm{N}_{50} \mathrm{P}_{100} \mathrm{~K}_{70}$ & 25.0 & 24.6 & 34.4 & 26.4 \\
3 & Background + Mn-2.5 & 33.0 & 26.8 & 37.5 & 29.5 \\
4 & Background + Mn-5.0 & 38.0 & 29.2 & 41.3 & 31.7 \\
5 & Background + Mn-7.5 & 36.0 & 27.6 & 38.0 & 30.4 \\
6 & Background + S-1.5 & 30.0 & 27.0 & 36.6 & 29.8 \\
7 & Background + S-3.0 & 37.3 & 30.0 & 39.4 & 31.7 \\
8 & Background + S-4.5 & 36.4 & 28.0 & 38.6 & 30.9 \\
\hline
\end{tabular}

compared to the background variant. When the element manganese was used in high doses, the protein content of the grain was $44.6 \%-47.1 \%$, which was $5.8 \%$ $8.5 \%$ higher than the control variant and $4.2 \%-5.7 \%$ higher than the background variant. It was found that the content of protein in the Orzu variety increased by $4.2 \%-8.4 \%$ according to the norms when using the element sulfur. In the Nafis variety, the protein content increased by $6.1 \%-8.0 \%$ compared to the control variant. The patterns are not the same in varieties due to the biological properties of these varieties and the demand of the varieties for the element sulfur (Table 3).

\section{Conclusions}

1) Mineral fertilizers and micronutrients affect the development of soybean varieties; the praxis period of soybean varieties is extended by $1-2$ days in exchange for mineral fertilizers, $4-6$ days in exchange for manganese and sulfur elements;

2) Mineral fertilizers and micronutrients affected the growth of soybean varieties; mineral fertilizers had a positive effect on the growth of both varieties, ensuring the growth of stem growth by $6-6.8 \mathrm{~cm}$. It was found that the stem height of soybean varieties in exchange for the element manganese was in the range of $11-20 \mathrm{~cm}$, and in the range of $10-17 \mathrm{~cm}$ in exchange for sulfur;

3) It was noted that when using the manganese element, the leaf surface was 5.7 - 8.6 thousand $\mathrm{m}^{2} /$ ha compared to the control variant, and $5.7-9.4$ thousand $\mathrm{m}^{2} / \mathrm{ha}$ in exchange for the sulfur element;

4) The number of tubers on soybean varieties increased by $2.2-22.3$ pieces due to mineral fertilizers, manganese; and it was found that the number of tubers by varieties increased by $2.7-18.1$ in exchange for the sulfur element;

$5)$ In the soybean varieties, mineral fertilizers were used in the variant with an additional yield of around $5-12 \mathrm{c} / \mathrm{ha}$ compared to the control. According to the norms of the manganese element, around $7-20 \mathrm{c} / \mathrm{ha}$; when using sulfur, the yield in soybean varieties is around $8.0-18.0 \mathrm{c} / \mathrm{ha}$; 
Table 3. Effect of micro elements on grain quality, \%.

\begin{tabular}{cccc}
\hline \multirow{2}{*}{ No. } & Variants & \multicolumn{2}{c}{ Varieties } \\
\cline { 3 - 4 } & Control & Orzu & Nafis \\
\hline 1 & Background $-\mathrm{N}_{50} \mathrm{P}_{100} \mathrm{~K}_{70}$ & 40.8 & 38.6 \\
2 & Background + Mn-2.5 & 41.9 & 41.4 \\
3 & Background + Mn-5.0 & 43.0 & 44.8 \\
4 & Background + Mn-7.5 & 44.6 & 46.1 \\
5 & Background + S-1.5 & 43.0 & 47.1 \\
6 & Background + S-3.0 & 45.2 & 44.7 \\
7 & Background + S-4.5 & 47.2 & 45.8 \\
8 & &
\end{tabular}

6) On the background of mineral fertilizers, grain quality has changed due to micronutrients. Protein content in the "Orzu" variety increased by $3.1 \%-8.4 \%$ when manganese and sulfur elements were used; in the "Nafis" variety, the protein content was found to increase by $6.1 \%-8.5 \%$.

\section{Conflicts of Interest}

The authors declare no conflicts of interest regarding the publication of this paper.

\section{References}

[1] Atabaeva, Kh.N., Israilov, I.A. and Umarova, N.S. (2011) Soybean-Morphology, Biology, Cultivation Technology, T. TSAU, 6.

[2] Agafonov, E.V., Agafonova, L.N. and Gujvin, S.A. (2005) Application of Mineral and Bacterial Fertilizers under Soybean. Agrochemistry Vestnik, No. 5, 18-20.

[3] Basibekov, B.O. and Gusev, V. (1982) Nauchnye osnovy i rekomendatsii po primineniyu udobreniy v Kazaxstane, Olma-ota, Kaynar. J. Maslichnii kulturi, 74-77.

[4] Barchukova, A.Y., Tabibullaev, E.Sh., Tsikunkova, T.V. and Xrenovskiy, V.Yu. (2002) Application of New Drugs for Inoculation of Soybeans. Zemledelie, No. 3, 26-27.

[5] Yormatova, D.E. and Soybean, T. (1989) Mehnat. 96.

[6] Larina, R.E. and Demidova, V.N. (2018) Features of the Formation of Soybean Yield in the Conditions of the Central Zone of the Nechernozemnoy Zone. Problems of Agrochemistry and Ecology, , No. 4, 27-33

[7] Gujvin, S.A. (2004) Influence of Mineral and Bacterial Fertilizers on Yield and Quality of Soybean Seeds. Strategy of Development of ARK: Technologies, Economics, Processing, Management. Materials of the International Scientific-Practical Conference, pos. Persinovskiy, Russ, 2-6 February 2004, 50.

[8] Zaveryuxin, V.I. and Levandovskiy, I.L. (1984) Polyv i udobreniya. Maslichnye kulturi. 1.

[9] Gubanov, P.E., Koliberda, K.F. and Kormilitsin, V.F. (1987) Soi na oroshaemyx zemlyax Povoljya. M. Russelkhozizdat, 60-75. 
[10] Larina, R.E. and Demidova, V.N. (2018) Osobennosti formirovaniya urojaya soi v usloviyax centralnoy zony Nechernozemnoy zony. Problemy Agroximii i Ekologii, No. 4, 27-33.

[11] http://www.agrodialog.com.ua 